\title{
UDP-Glucuronosyltransferase 2B15
}

National Cancer Institute

\section{Source}

National Cancer Institute. UDP-Glucuronosyltransferase 2B15. NCI Thesaurus. Code C105422.

UDP-glucuronosyltransferase 2B15 (530 aa, $61 \mathrm{kDa}$ ) is encoded by the human UGT 2B15 gene. This protein is involved in the catabolism of xenobiotics and steroids. 